\title{
OPTIMALISASI PELAYANAN PUBLIK SECARA ONLINE PADA KANTOR WILAYAH KEMENTERIAN HUKUM DAN HAM PROVINSI SULAWESI TENGGARA
}

\author{
'Suriyani BB, ${ }^{2}$ Suci Amalya Widiastuti \\ 1,2, Jurusan IImu Administrasi Publik, Fakultas IImu Sosial \& IImu Politik,Universitas Halu Oleo \\ Email: suriyanibb@gmail.com, scamalya@gmail.com \\ Kota Kendari, Kode pos : 93232, Indonesia
}

\begin{abstract}
This study aims to determine and describe optimizing public services online at the regional office of the Ministry of the Law and Human Rights in Southeast Sulawesi, this study uses descriptive qualitative methods to 5 informants determined by snowball sampling technique, data analysis techniques consist of data collection, data reduction, presentation data, drawing conclusions/verification, the data obtained were analyzed qualitatively and described in descriptive form. The results of this study indicate that public services carried out online at the regional office of the Ministry of Law and Human Rights in Southeast Sulawesi are very good, this can be seen from the implementation of services with standard operating procedures that apply during the pandemic and the handling that is in accordance with what has been determined at the regional office of the Ministry of Law and Human Rights by upholding the values of professionalism, accountability, synergy, transparency, and innovation. Based on the research, one form of research on optimizing public services is the existence of a digital based service system that makes it easier for the public to receive services, supporting facilities and infrastructure, as well as services provided quickly and responsively at the regional of the Ministry of Law and Human Rights in Southeast Sulawesi.
\end{abstract}

Keywords: Online; Optimization; Publik Services

\begin{abstract}
Abstrak
Penelitian ini bertujuan untuk mengetahui dan mendeskripsikan optimalisasi pelayanan publik secara online pada Kantor Wilayah Kementerian Hukum dan HAM Sulawesi Tenggara, penelitian ini menggunakan metode kualitatif deskriptif terhadap 5 orang informan, analisis data terdiri dari pengumpulan data, reduksi data, penyajian data, penarikan kesimpulan/verivikasi, data yang diperoleh dianalisis secara kualitatif serta diuraikan dalam bentuk desktiptif. Hasil penelitian ini menunjukan bahwa Pelayanan Publik yang dilakukan secara online Pada Kanwil Kemenkumham Sulawesi Tenggara sudah sangat baik hal ini dapat dilihat dari terlaksananya pelayanan dengan standar operasional prosedur yang berlaku pada masa pandemi serta penanganan yang sudah sesuai dengan apa yang ditetapkan pada pihak kemenkumham dengan menjunjung nilai professional, akuntabel, sinergi, transparan dan inovatif. Berdasarkan penelitian ini bahwa salah satu bentuk optimalisasi pelayanan publik adanya sistem pelayanan berbasis digital yang memudahkan masyarakat dalam menerima pelayanan, sarana dan prasarana yang menunjang, serta pelayanan yang diberikan cepat dan tanggap pada Kantor Wilayah Kementerian Hukum dan HAM Provinsi Sulawesi Tenggara.
\end{abstract}

Kata Kunci: Online; Optimalisasi; Pelayanan Publik

Open Access at:http://ojs.uho.ac.id/index.php/PUBLICUHO/index

Journal Publicuho is licensed under a Creative Commons Attribution 4.0 International License. 


\section{Journal Publicuho}

ISSN2621-1351 (online), ISSN 2685-0729 (print)

Volume 4 Number 4 (November - January), (2021) pp. 1272-1280 Accredited SINTA SK.NOMOR 28/E/KPT/2019 Open Access at:http://ojs.uho.ac.id/index.php/PUBLICUHO/index ～DOl: http://dx.doi.org/10.35817/jpu.v4i4.23234

\section{PENDAHULUAN}

Pelayanan Publik adalah suatu tindakan pemberian barang dan jasa kepada masyarakat oleh pemerintah dalam rangka tanggung jawabnya kepada publik, baik diberikan secara langsung maupun melalui kemitraan dengan swasta dan masyarakat, berdasarkan jenis, intensitas kebutuhan masyarakat, dan kemampuan masyarakat dipasar. Konsep ini lebih menekankan bagaimana pelayanan publik berhasil diberikan melalui suatu delivery sistem yang sehat (Saleh,2010)

Dalam menghadapi era globalisasi yang penuh tantangan dan peluang, aparatur negara dalam hal ini dititik beratkan kepada aparatur pemerintah hendaknya memberikan pelayanan yang sebaik-baiknya, berorientasi pada kebutuhan, dan kepuasan penerima pelayanan, sehingga dapat meningkatkan daya saing dalam pemberian pelayanan barang dan jasa (Surjadi,2009)

Inovasi dalam penelitian administrasi publik termasuk dalam perspektif New Public Administration dan Innovative Government. Konsep ini menjelaskan kemampuan organisasi untuk bertahan dan meningkatkan kinerja dengan menerapkan semangat sektor swasta ke sektor publik. Dalam hal ini, ditegaskan bahwa tanpa sistem administrasi atau manajemen yang inovatif dan adaptif, kebijakan inovasi pasti akan gagal. Artinya, inovasi merupakan bagian penting dari operasional pemerintah untuk mencapai tujuan organisasi.

Sejak dikeluarkannya PP Nomor 21 Tahun 2020 tentang Pembatasan Sosial Berskala Besar Dalam Rangka Percepatan Penanganan Corona Virus Disease (Covid-19) pada tanggal 31 Maret 2020, beberapa wilayah di tanah air memberlakukan PSBB (Pembatasan Sosial Berskala Besar) yang menyebabkan sekolah dan tempat kerja diliburkan, kegiatan keagamaan atau ibadah bersama dibatasi dan kegiatan-kegiatan di tempat umum atau fasilitas publik juga dibatasi. Hal ini untuk menghindari terjadinya kerumunan banyak orang agar resiko penularan virus ini dapat ditekan. Pemberlakuan Pembatasan Sosial di Indonesia juga membawa dampak pada aksesibilitas pelayanan publik. Surat Edaran yang dikeluarkan oleh Menteri Pendayagunaan Aparatur Negara dan Reformasi Birokrasi (PANRB) Nomor 19 Tahun 2020 tentang Penyesuaian Sistem Kerja Aparatur Sipil Negara Dalam Upaya Pencegahan Penyebaran covid-19 Di Lingkungan Instasi Pemerintah. Surat Edaran ini memberlakukan work from home (bekerja di rumah) secara bergantian bagi para pegawai di Lingkungan Instansi Pemerintah.

Pemerintah diharuskan menyesuaikan segala kebijakan-kebijakan dengan keadaan normal baru (new normal), akibatnya banyak kebijakan yang harus diubah bahkan dihapuskan. 
ISSN2621-1351 (online), ISSN 2685-0729 (print

Volume 4 Number4 (November - January), pp.1272-1280

Suriyani Bunga Batara, Suci Amalya P. DOI: http://dx.doi.org/10.35817/jpu.v4i4.23234

Namun di sisi lain pihak penyelenggara pelayanan publik dituntut agar tetap dapat melakukan pelayanan kepada masyarakat dengan selalu memperhatikan hak dan kewajiban pihak terkait. Masalah yang menjadi hambatan dalam penyelenggaraan pelayanan publik ini sekaligus menjadi tantangan dalam masa pandemi Covid-19. Keluhankeluhan yang dirasakan masyarakat dapat berdampak kepada kinerja pemerintahan yang akan menghilangkan kepercayaan dari masyarakatnya. Oleh karena itu hasil evaluasi yang dilakukan dapat dijadikan acuan perbaikan kebijakan untuk meningkatkan kualitas pelayanan yang diberikan kepada masyarakat dengan mengoptimalkan prinsip-prinsip kerja good governance (Amalia,2021)

Berdasarkan Peraturan Menteri Hukum dan Hak Asasi Manusia R.I Nomor M.HH-05.OT.01.01 Tahun 2010 tentang Organisasi dan Tata Kerja Kementerian Hukum dan Hak Asasi Manusia, Kementerian Hukum dan Hak Asasi Manusia mempunyai tugas menyelenggarakan urusan di bidang hukum dan hak asasi manusia dalam pemerintahan untuk membantu Presiden dalam menyelenggarakan pemerintahan negara. Dalam rangka meningkatkan pelayanan kepada masyarakat telah dilakukan penerapan teknologi informasi dan komunikasi serta perbaikan kerangka regulasi pelayanan badan hukum melalui sistem administrasi badan hukum, pelayanan dan pengawasan keimigrasian melalui pembangunan dan pengembangan sistem informasi.

Untuk memberikan kemudahan bagi masyarakat dalam mengakses setiap layanan dan perlindungan dalam hal ini pada Kantor Wilayah Kementrian Hukum dan Ham Provinsi Sulawesi Tenggara. Untuk itu, dibutuhkan perubahan bagi Aparatur Sipil Negara dalam pelayanan publik, mengubah pelayanan birokrasi dari manual dan konvensional, menjadi otomatis dan digital.

Terdapat beberapa kendala yang terjadi pada saat penerapan pelayanan publik secara online Bidang Administrasi Hukum Umum pada Kantor Wilayah Kementrian Hukum dan Ham Provinsi Sulawesi Tenggara:

a. Akses yang diberikan Ke Kanwil sangat terbatas

b. Pelayanan yang diberikan hanya sebatas Konsultasi saja selanjutnya diserahkan ke Notaris yang menjadi bagian dari jasa layanan Kemenkumham.

Berdasarkan hasil observasi awal penulis diketahui bahwa dikarenakan pandemi covid 19 ini menyebabkan kurang optimalnya pelayanan sehingga Kanwil tidak punya banyak kewenangan lagi. Perubahan layanan bukan sekedar menjadi online dengan menggunakan aplikasi digital namun harus diikuti dengan perubahan perilaku pegawai serta didukung dengan sumberdaya yang memadai. Seyogyanya pelayanan pada Kantor Wilayah Kementrian Hukum dan Ham Provinsi Sulawesi Tenggara ini bisa dibilang menuju 


\section{Journal Publicuho}

ISSN2621-1351 (online), ISSN 2685-0729 (print)

Volume 4 Number 4 (November - January), (2021) pp. 1272-1280 Accredited SINTA SK.NOMOR 28/E/KPT/2019 Open Access at:http://ojs.uho.ac.id/index.php/PUBLICUHO/index $\quad$ DOl: http://dx.doi.org/10.35817/jpu.v4i4.23234

optimal yang ditandai dengan pemberian predikat WBK (Wilayah Bebas Korupsi) oleh Kementrian PANRB tahun 2020. Namun Tidak ada instansi yang 100\% pelayanannya benar benar optimal pasti ada kendala atau beberapa permasalahan yang dihadapi dalam pemberian pelayanan, begitu juga yang dihadapi pada Kantor Wilayah Kementrian Hukum dan Ham Provinsi Sulawesi Tenggara apalagi dimasa Pandemi covid - 19 seperti sekarang ini. Berdasarkan latar belakang diatas penulis tertarik untuk melakukan penelitian yang berjudul "Optimalisasi Pelayanan Publik Secara Online Pada Kantor Wilayah Kementrian Hukum dan HAM Provinsi Sulawesi Tenggara"

\section{METODOLOGI}

Metode yang dilakukan dalam penelitian ini yaitu menggunakan metode pendekatan kualitatif, yaitu sebagai prosedur penelitian yang menggunakan data deskriptif berupa katakata tertulis atau lisan dari orang-orang dan perilaku yang diamati. Adapun jenis penelitian ini adalah penelitian kualitatif secara deskriptif yang bertujuan untuk mendeskripsikan apaapa yang saat ini berlaku juga dimaksudkan sebagai proses pemecahan masalah yang diselidiki dengan melukiskan keadaan subyek obyek berdasarkan fakta-fakta yang ada.

Teknik penentuan informan yang digunakan dengan pertimbangan tertentu atau penentuan informasi berdasarkan tujuan dan kebutuhan peneliti, sehingga informan mampu memberikan keterangan dan informasi mengenai permasalahan dalam penelitian ini. Informan penelitian sebanyak 5 orang yang terdiri dari Staf Kantor Wilayah Kementerian Hukum dan HAM Provinsi Sulawesi Tenggara, Notaris sebagai pengguna layanan jasa Kemenkumham, dan Masyarakat Kota Kendari. Adapun sumber data dalam penelitian ini adalah menggunakan data primer dan sekunder. Teknik pengumpulan data dilakukan dengan observasi, wawancara dan dokumentasi.

\section{HASIL DAN PEMBAHASAN}

Menurut Dwiyanto (2006:56) yang dikutip dari La Ode Muhammad Elwan. (2019) bahwa pemberian pelayanan publik oleh aparatur pemerintah kepada masyarakat (publik) merupakan perwujudan dan fungsi aparatur negara sebagai pelayan masyarakat (abdi), disamping sebagai abdi negara. Dalam konteks ini masyarakatlah sebagai aktor utama (pelaku) pembangunan, sedangkan pemerintah berkewajiban untuk mengarahkan, membimbing serta menciptakan suasana yang menunjang kegiatan-kegiatan dari masyarakat tersebut. Pada kondisi ini aparatur negara dituntut untuk lebih mampu memperbaiki kinerjanya (pelayanan prima) dan diharapkan lebih mampu merumuskan konsep atau menciptakan iklim yang kondusif, sehingga sumber daya pembangunan dapat menjadi pendorong percepatan terwujudnya masyarakat yang mandiri dan sejahtera. Pelayanan yang telah menunjuk kepada aturan formal dianggap telah memenuhi sendi- 
ISSN2621-1351 (online), ISSN 2685-0729 (print

Volume 4 Number4 (November - January), pp.1272-1280

Suriyani Bunga Batara, Suci Amalya P. DOI: http://dx.doi.org/10.35817/jpu.v4i4.23234

sendi pelayanan yang baik dan aparat pelayanan dianggap telah konsisten dalam menerapkan aturan hukum pelayanan. (Muhammad Elwan, 2019)

\section{A. Optimalisasi}

Rumusan masalah pertama yang ingin dijawab dalam skripsi ini adalah bagaimana "Optimalisasi Pelayanan Publik Secara Online Pada Kantor Wilayah Kementerian Hukum dan HAM Provinsi Sulawesi Tenggara". Pelayanan secara online ini sebagai bentuk birokrasi digital yang ditujukan untuk mempermudah dalam menerima pelayanan yang dibutuhkan masyarakat. Optimalisasi Pelayanan publik yang dilakukan secara online Pada Kantor Wilayah Kementerian Hukum dan HAM Provinsi Sulawesi Tenggara mempunyai tiga elemen optimalisasi Erwin (2013) dikatakan bahwa ada tiga elemen yang harus diidentifikasi yaitu tujuan optimalisasi, alternatif keputusan, dan sumberdaya yang terbatas. Ketiga elemen ini yang menentukan keberhasilan suatu pekerjaan yang dilakukan oleh aparatur dalam mengembang tugas pelayanan administrasi kepada publik dan merupakan bentuk ukuran optimalisasi pelayanan publik secara online pada Kanwil Kemenkumham Sulawesi Tenggara.

\section{Tujuan Optimliasasi}

Tujuan yang dimaksudkan disini adalah memaksimalkan atau meminimalkan suatu pemberian pelayanan. Sistem Pelayanan Publik secara online yang dilakukan pada Kantor Kementerian Hukum dan HAM Sulawesi Tenggara sudah maksimal dengan adanya pelayanan berbasis digital yang memudahkan pengguna layanan Kemenkumham dalam mencapai tujuannya. Dan hal yang perlu diminimalkan dalam pemberian pelayanan adalah pembatasan masyarakat yang hendak ke Kantor untuk melakukan pelayanan konsultasi sebagai bentuk menaati prokes yang berlaku saat ini.

\section{Alternatif Keputusan}

Alternatif keputusan adalah kegiatan pelayanan konsultasi untuk mencapai tujuan dalam membantu masyarakat dengan menggunakan sumberdaya yang dimiliki yang dihadapkan dengan beberapa pilihan yang perlu dipertimbangkan dengan baik. Alternatif keputusan yang diberikan Kantor Wilayah Kementerian Hukum dan HAM Provinsi Sulawesi Tenggara dengan mengurangi pelayanan yang bersifat manual artinya pelayanan lebih ke online, juga sebagai wujud menciptakan birokrasi digital.

Tanggapan masyarakat juga bervariatif mengenai pelayanan yang masih dibilang baru ini ada yang merasa pelayanan online ini memudahkan karena cepat dan tanpa ke Kantor dan ada juga yang merasa pelayanan online ini kurang bagus karena masalah jaringan atau pengiriman dokumen dokumen yang menurut masyarakat ribet.

\section{Sumberdaya yang Terbatas}

Adanya ketersediaan sumberdaya keterlibatan ini mengakibatkan dibutuhkannya proses optimalisasi pada Kantor Wilayah Kementerian Hukum dan HAM Provinsi Sulawesi Tenggara. 


\section{Journal Publicuho}

ISSN2621-1351 (online), ISSN 2685-0729 (print)

Volume 4 Number 4 (November - January), (2021) pp. 1272-1280 Accredited SINTA SK.NOMOR 28/E/KPT/2019 Open Access at:http://ojs.uho.ac.id/index.php/PUBLICUHO/index $\quad$ DOl: http://dx.doi.org/10.35817/jpu.v4i4.23234

Keterbatasan Sumberdaya manusia yang ada pada Kantor Wilayah Kementerian Hukum dan HAM Provinsi Sulawesi Tenggara, yaitu operator hanya dua orang untuk pendaftaran permohonan hak cipta, dan merek dimana meningkatnya UMKM, banyak masyarakat yang mengeluh pelayanannya harus menunggu lebih lama karena kurangnya operator. Pegawai Kanwil Kemenkumham juga selalu meningkatkan wawasan mengenai pelayanan publik secara online dengan selalu mengikuti pelatihan atau pendidikan mengenai teknologi informasi. Sehingga sumberdaya merupakan hal yang penting dalam pelayanan secara online.

\section{B. Pelayanan Publik}

Pelayanan publik secara online adalah pelayanan yang dilakukan dengan bantuan teknologi internet dimana memungkinkan berbagai jenis urusan bisa selesai dengan mudah tanpa melakukan tatap muka, namun tentu saja ada faktor - faktor yang dihadapi pegawai dalam penerapan pelayanannya baik itu kendala jaringan, pegawai yang kurang mempunyai kemampuan dalam teknologi informasi, serta manajemen waktu yang kurang tepat.

Faktor - faktor tersebut juga yang dapat berpengaruh terhadap optimalisasi pelayanan publik yang ada pada Kantor Wilayah Kementerian Hukum dan HAM Provinsi Sulawesi Tenggara, ada 5 (lima) indikator yang perlu diperhatikan dalam mengoptimalkan pelayanan publik yaitu: wujud, kehandalan, ketanggapan, jaminan dan empati.

Melihat mengenai kelima indikator tersebut maka dibahas satu persatu sebagai berikut:

\section{Wujud (Tangibles)}

Wujud adalah pemberian pelayanan yang berhubungan dengan fasilitas fisik, perlengkapan, personel, dan sarana komunikasi yang lengkap sehingga memudahkan pekerjaan serta menunjang pelayanan publik secara online sehingga masyarakat puas akan layanan yang diberikan pada Kantor Wilayah Kementerian Hukum dan HAM Provinsi Sulawesi Tenggara.

\section{Kehandalan (Realibility)}

Kehandalah merupakan pemberian pelayanan publik yang diharapkan masyarakat sudah sesuai janji yang ditawarkan oleh pegawai Kantor Wilayah Kementerian Hukum dan HAM Provinsi Sulawesi Tenggara. Kehandalan yang dilakukan oleh pegawai Kanwil Kemenkumham sangat baik dalam memberikan pelayanan konsultasi hukum proses administrasinya dilakukan dengan cepat, efektif, dan efesien guna memberikan pelayanan yang terbaik untuk masyarakat.

\section{Ketanggapan (Responsiveness)}

Ketanggapan yang dimaksud disini adalah pemberian pelayanan publik khusunya pelayanan konsultasi hukum dengan cepat, tepat, dan tanggap kepada masyarakat, 
ISSN2621-1351 (online), ISSN 2685-0729 (print

Volume 4 Number4 (November - January), pp.1272-1280

Suriyani Bunga Batara, Suci Amalya P. DOI: http://dx.doi.org/10.35817/jpu.v4i4.23234

baik pelayanan melalui online maupun pelayanan secara manual oleh pegawai Kantor Wilayah Kementerian Hukum dan HAM Provinsi Sulawesi Tenggara.

\section{Jaminan (Assurance)}

Pelayanan yang diberikan oleh pihak Kantor Wilayah Kementerian Hukum dan HAM Provinsi Sulawesi Tenggara mencakup pengetahuan informasi mengenai layanan konsultasi hukum dengan keramah tamahan, perhatian, dan kesopanan dalam memberikan jaminan pelayanan yang terbaik untuk masyarakat.

Jaminan yang diberikan Kantor Wilayah Kementerian Hukum dan HAM Sulawesi Tenggara ditandai dengan adanya pemberian predikat WBK atau Wilayah Bebas Korupsi yang diberikan oleh MENPAN RB yang artinya tidak ada pungli dan benar benar transparan dalam pemberian pelayanan publik kepada masyarakat.

\section{Empati (Empathy)}

Empati suatu pemberian perhatian yang diberikan kepada pengguna layanan serta berusaha memahami keinginan serta mampu menangani keluhan penerima pelayanan secara baik dan cepat yang dilakukan oleh pihak Kantor Wilayah Kementerian Hukum dan HAM Provinsi Sulawesi Tenggara.

Sekarang sistem pelayanan publik dilakukan secara online dimana masih ada beberapa kendala seperti jaringan yang kurang mendukung serta kurang pahamnya mengenai informasi pelayanan yang diberikan namun pegawai selalu berusaha memahami dan memberikan informasi dengan jelas mengenai layanan hukum yang diberikan untuk masyarakat.

\section{KESIMPULAN}

Berdasarkan hasil dan pembahasan maka dapat ditarik kesimpulan penelitian sebagai berikut:

1. Pelayanan publik sudah dilakukan secara optimal, bentuk pengoptimalisasiannya adalah dengan adanya sistem pelayanan berbasis digital yang memudahkan masyarakat dalam mendapatkan pelayanan tanpa perlu langsung ke kantor, jangka waktu penyelesaiannya cepat, sarana prasarananya juga menunjang baik dalam pelayanan secara online maupun manual, dan dalam hal pelayanan konsultasi hukum juga tanpa dipungut biaya sepeserpun, serta penanganan pengaduan dilakukan dengan tanggap oleh pegawai Kantor Wilayah Kementerian Hukum dan HAM Provinsi Sulawesi Tenggara.

2. Dalam hal pelayanan publik secara online tentu saja masih ada faktor - faktor kendala yang tejadi pada saat penerapan pelayanan secara online yaitu akses yang dibeikan kanwil sangat terbatas pelayanannya yaitu hanya sebatas konsultasi saja selanjutnya diserahkan ke notaris, sumberdayanya juga masih kurang, serta jaringan yang kurang 


\section{Journal Publicuho}

ISSN2621-1351 (online), ISSN 2685-0729 (print)

Volume 4 Number 4 (November - January), (2021) pp. 1272-1280 Accredited SINTA SK.NOMOR 28/E/KPT/2019

Open Access at:http://ojs.uho.ac.id/index.php/PUBLICUHO/index $\quad$ DOl: http://dx.doi.org/10.35817/jpu.v4i4.23234

mendukung dalam pelayanan secara online sehingga biasa terjadi miss komunikasi antar pemberi pelayanan dan penerima pelayanan.

\section{REFERENSI}

Bharata, Atep Adya. 2003. Dasar- Dasar Pelayanan Prima. Jakarta: PT. Gramedia. Pustaka.

Erwin, Aditya Pratama, Optimalisasi Pengelolaan Zakat Sebagai Sarana Mencapai Kesejahteraan Sosial, (Semarang: UNNES 2013)

Dwiyanto, Agus. 2006. Mewujudkan Good Governance Melalui Pelayanan Publik. Yogyakarta: Gajah Mada University Press

Hayat. 2017. Manajemen Pelayanan Publik. PT Raja Grafindo Persada, Depok.

Kasmir. 2006. Kewirausahaan, Jakarta : Raja Grafindo Persada

Lukman, Sampara. 2000. Manajemen Kualitas Pelayanan. Jakarta, STIA LAN Press.

Miles, M. B. \& Huberman, M. (2012). Analisis Data Kualitatif. Jakarta: Penerbit Universitas Indonesia

Muhammad Elwan, La Ode. "Problem Birokrasi dalam Meningkatan Pelayanan Publik pada Sekretariat Daerah Kabupaten Muna." Journal Publicuho, vol. 2, no. 2, 2019, pp. 31-42, doi:10.35817/jpu.v2i2.7223.

Moenir. 2002. Manajemen Pelayanan Umum di Indonesia.Yogyakarta: PT Bumi Aksar

Napitupulu, Aimin. 2007, Menuju Pemerintahan Perwakilan, PT. Alumni, Bandung.

Ndraha, Taliziduhu. 2000. Kybernologi (IImu Pemerintah Baru). Jilid 1-2 Rineka Cipta. Jakarta

Peraturan Pemerintah No. 96 Tahun 2012 Tentang Pelayanan Publik

Peraturan Menteri PANRB No 63 Tahun 2003 Tentang Pedoman Umum Penyelenggaraan Pelayanan Publik

Peraturan Menteri Hukum dan Hak Asasi Manusia No 28 Tahun 2014 Tentang Tugas dan Fungsi Kantor Wilayah

Poltak, Lijen S. 2006. Reformasi Pelayanan Publik, Teori, Kebijakan dan. Implementasi, Bumi Aksara, Jakarta

Prasojo, Eko. 2006. Aditya perdana, Norr Hiamah, Kinerja Pelayanan Publik: Persepsi Masyarakat terhadap Kinerja, Keterlibtan dan Partisipasi dalam Pelayanan Pendidikan, Kesehatan dan Kependudukan, Jakarta:Yappika.

Ratminto dan Atik Septi W. 2010. Manajemen Pelayanan. Yogyakarta: Pustaka Pelajar

S. Amalia, "Reformasi Birokrasi 4.0 : Strategi Menghadapi Revolusi Industri 4.0," J. Wacana Kinerja Kaji. Prakt. Kinerja dan Adm. Pelayanan Publik, vol. 21, no. 2, 2018.

Saleh, Muwafik. 2010. Public Service Comnunication (praktik komunikasi dalam Pelayanan Publik), UMM Press, Malang

Sidik, Machfud. 2001, "Optimalisasi Pajak Daerah Dan Retribusi Daerah Dalam Rangka Meningkatkan Kemampuan Kevangan Daerah", Artikel 
ISSN2621-1351 (online), ISSN 2685-0729 (print

Volume 4 Number4 (November - January), pp.1272-1280

DOI: http://dx.doi.org/10.35817/jpu.v4i4.23234

Suriyani Bunga Batara, Suci Amalya P.

Sinambela L.P .2010. Reformasi Pelayanan Publik. Teori, Kebijakan dan Implementasi. Jakarta: Bumi Aksara

Surjadi. 2009. Pengembangan Kinerja Pelayanan Publik, Refika Aditama, Bandung

Susanti, Y. (2015). Sistem Pelayanan on-Line. Jurnal Media Infotama, 11 (2)

Tangkilisan, Hessel Nogi, 2005, Manajemen Publik. Jakarta : Grasindo

Undang-Undang nomor 25 tahun 2009 Tentang Pelayanan Publik

Winardi. (1999). Pengantar tentang Teori Sistem dan Analisis Sistem. Bandung : Mandar Maju. 